\title{
Pengembangan Board Game untuk Meningkatkan Minat Belajar Siswa Kelas IV SD
}

\author{
Nadia Nurfaizah \\ Universitas Negeri Jakarta \\ nurfaizahnadia24@gmail.com \\ Arifin Maksum \\ Universitas Negeri Jakarta \\ arifinmaksum@gmail.com \\ Prayuningtyas Angger Wardhani \\ Universitas Negeri Jakarta \\ prayuningtyasangger@gmail.com
}

\begin{abstract}
Board games can be used as learning media to help the Civics learning process on the meaning of the relationship between the symbols and the Pancasila precepts in Theme 4 (various jobs). The purpose of this study was to produce game-based learning media in order to increase the learning interest of fourth grade students towards the content of Civics subjects. This research is a development research with a modified ADDIE development model. This development model consists of stages of analysis, design, development, implementation and evaluation. This stage in research and development is carried out until the development stage. The instrument used in this study was a questionnaire to analyze the needs of teachers and students as well as a validation instrument for experts. Data collection techniques using quantitative and qualitative data. The results of the study indicate that the board game media is suitable for use in Civics subjects for grade IV SD with reference to the results of expert validation. The results of media expert validation are $74 \%$ or Valid. The results of validation by linguists obtained a percentage of $80 \%$ or Valid.
\end{abstract}

Keywords: media pembelajaran, Board Game, PPKn, minat belajar

\section{Pendahuluan}

Proses pembelajaran tentunya mengharapkan agar peserta didik dapat memperoleh hasil belajar yang baik. Namun, harus disadari untuk memperoleh hasil belajar yang baik perlu didukung oleh kemampuan pendidik dalam proses pembelajaran tersebut. Penelitian telah menunjukkan bahwa minat berkaitan dengan pelajar, pemilihan strategi yang juga memprediksi hasil belajar mereka (Syawaluddin et al., 2020). Dalam proses belajar, peserta didik harus mempunyai minat atau kesukaan yang dapat mendorongnya agar menunjukan perhatian dan berusaha memahami apa yang sedang dipelajari (Rusmiati, 2017). Sejalan dengan pernyataan tersebut, menurut Slameto (2010: 180), minat besar pengaruhnya terhadap hasil belajar, karena siswa tidak akan belajar dengan sebaik-baiknya jika tidak ada daya tarik terhadap bahan yang dipelajari. Oleh karena itu, seorang pendidik perlu memberikan rangsangan kepada siswa untuk membuatnya tertarik dan berpartisipasi dalam proses pembelajaran (Saswandi et al., 2014). Pemberian rangsangan menjadi hal penting untuk diterapkan khususnya pada muatan pelajaran yang cendrung kurang diminati siswa, salah satunya yaitu Pendidikan Pancasila dan Kewarganegaraan (PPKn). 
Jika dicermati, pada hakikatnya PPKn menjadi pelajaran penting yang tidak kalah dari pelajaran lainnya. PPKn sangat besar andilnya dalam membentuk kepribadian warga negara yang cerdas. Menurut National Council of Social Studies (NCSS) Amerika Serikat, PKN bukanlah sekedar bidang studi melainkan lebih dari itu. Hal ini dikarenakan PKN dapat memberikan pengaruh positif untuk membentuk pandangan seorang warga negara dalam peranannya di masyarakat.

Berdasarkan pengertian PPKn yang dikemukan oleh Nu'man Somantri (Program pendidikan yang berintikan demokrasi politik, yang diperluas dengan sumbersumber pengetahuan lainnya, positive influence pendidikan sekolah, masyarakat, orang tua, yang kesemuanya itu diproses untuk melatih pelajar-pelajar berpikir kritis, analitis, dan bertindak demokratis dalam mempersiapkan hidup demokratis dengan berlandaskan Pancasila dan UUD 1945) dapat dipahami bahwa materi pokok dalam PPKn sebenarnya diproses untuk melatih para peserta didik berpikir kritis dan analitis serta mampu bersikap dan bertindak demokratis sesuai dengan nilainilai pancasila. Kurikulum 2013 menyatakan tujuan dari PPKn ialah untuk menyiapkan peserta didik menjadi warga negara yang tidak hanya menguasai pengetahuan, tetapi juga memiliki sikap dan keterampilan yang dapat mendorong mereka memiliki rasa kebangsaan dan cinta tanah air sebagai wujud implementasi dan aktualisasi nilai-nilai Pancasila (Rahmayani, 2016). Dari beberapa penjelasan diatas dapat disimpulkan bahwa PPKN diyakini mampu mengembangkan pengetahuan nilai Pancasila serta mengembangkan pembentukan sikap (Christopher et al., 2019). Dengan demikian PPKn sangat penting untuk dipelajari sejak dini.

Namun, kenyataan yang ada di lapangan memperlihatkan bahwa pembelajaran PPKn belum maksimal untuk mencapai tujuan yang diharapkan. Hal ini dikarenakan dalam proses pembelajarannya pendidik seringkali menerapkan metode yang monoton yaitu metode ceramah. Tujuan PPKn semestinya mampu membuat siswa berpikir kritis dan analitis. Akan tetapi proses pembelajaran PPKn yang ada di sekolah dasar (SD) masih bersifat tradisional (Andrew et al., 2019). Seperti masih berpusat pada pendidik (teacher center) dan bersifat satu arah (indoktrinasi). Sementara pembelajaran PPKn yang seperti ini belum mampu membuat siswa berpikir kritis. Lantaran proses pembelajaran yang dapat memenuhi kemampuan berpikir kritis siswa tidak dapat dilakukan hanya dengan proses pembelajaran yang bersifat satu arah (Trisdiono, 2013). PPKn sebagai pembelajaran yang mengutamakan penguasaan kompetensi juga harusnya berpusat pada siswa (Riyan Cahya \& Harmanto, 2018). Akan tetapi pada kenyataannya pembelajaran PPKn seringkali didominasi oleh pendidik. Selain itu pembelajaran PPKn yang seharusnya membuat siswa mampu mengimplementasikan nilai-nilai Pancasila seringkali hanya diarahkan pada pengetahuan semata. Sehingga berujung lemahnya sikap dan keterampilan siswa.

Wajar saja jika PPKn masih terkesan monoton dan kurang menarik sehingga cenderung kurang diminati siswa. Berdasarkan observasi yang dilakukan oleh Martona (2016) diperoleh hasil bahwa sekitar 55\% minat siswa dalam pembelajaran PPKn masih rendah. Selama proses pembelajaran berlangsung siswa kurang memperhatikan, malu bertanya, terlihat malas, dan jenuh. Sehingga, suasana pembelajaran yang harusnya menyenangkan tidak tercipta di kelas tersebut. Kendala dalam metode pengajaran PPKn yang juga ditemukan oleh Setiawan dan Karim (2020) yaitu siswa kurang antusias dan tidak tertarik dengan pembelajaran ini dikarenakan pengajaran yang terlalu tekstual, banyak menghafal, dan monolog yang diterapkan guru membuat siswa bosan. Hal inilah yang menyebabkan minat belajar siswa saat proses belajar PPKn sangat kurang. Menyikapi permasalahan yang ada, maka diharapkan pendidik memiliki strategi khusus yang mampu menumbuhkan minat siswa pada muatan pelajaran ini. 
Salah satu upaya yang bisa dilakukan oleh pendidik untuk menumbuhkan minat belajar siswa ialah melalui penggunaan media pembelajaran. Menurut Arsyad (dalam Sulasteri et al., 2018) dengan menggunakan media dalam proses belajar mengajar tidak hanya dapat membangkitkan motivasi siswa tetapi juga keinginan dan minatnya untuk belajar. Program pembelajaran adalah sesuatu yang mampu memberikan pemahaman kepada siswa untuk dapat diterapkannya dalam kehidupan, sehingga salah jika masih ada anggapan bahwa pembelajaran hanyalah sekedar rentetan topik atau pokok bahasan (Hamka L et al., 2017). Oleh karena itu diperlukan kreativitas pendidik dalam membuat media pembelajaran agar materi lebih mudah dipahami dan tentunya menjadikan pembelajaran lebih bermakna. Sebagaimana tuntutan pembelajaran abad 21, guru diharapkan mampu mendesain pembelajaran yang melibatkan peran siswa di kelas, cara yang dapat diterapkan guru misalnya adalah dengan belajar sambil bermain sehingga belajar tidak dirasa sebagai sebuah beban oleh siswa melainkan menjadi hal yang menyenangkan (Permanda, 2020).

Permainan menjadi salah satu media pembelajaran yang dapat dipilih guru untuk memberikan kemudahan kepada siswa dalam memahaminya (Rao, 2014). Salah satu bentuk permainan yang dapat dijadikan sebagai media dalam pembelajaran PPKn adalah Board Game. Menurut Berland dan Lee Board Games merupakan sebuah permainan yang memberikan kegiatan bersifat rekreatif, dimainkan secara berkelompok, dan dapat mengarahkan mereka bermain secara kompetitif, kooperatif, dan kolaboratif (Setiawan \& Abdulkarim, 2020). Lely Tobing menyatakan bahwa "Board game mampu mengajarkan banyak hal. Diantaranya ialah melatih konsentrasi serta daya ingat anak. Selain itu, Board Game juga dapat melatih anak usia sekolah untuk memecahkan masalah, berpikir kreatif dan kritis, serta berlatih strategi. Tiga aspek yang tercakup dalam Board Game yaitu aspek visual (gambar), audio (berdiskusi dan tanya jawab), serta afektif (sikap). Studi pendekatan permainan papan untuk akuisisi pengetahuan menemukan bahwa "guru dan peserta didik mengkonfirmasi efek permainan papan dalam meningkatkan motivasi belajar dan kesenangan dalam konteks konten yang sarat teori” (Taspinar et al., 2016, hlm. 115). PPKn menjadi salah satu muatan pelajaran yang sarat teori dan siswa dituntut agar berpikir kritis. Sehingga, penggunaan Board Game sesuai untuk diterapkan pada muatan pelajaran tersebut.

Beberapa peneliti telah menguji efektivitas penggunaan Board Game dalam pembelajaran. Diantaranya yaitu penelitian yang dilakukan oleh Theana Putri Permananda dan Wahyudi (2020) yang menguji efektifitas Board Game untuk meningkatkan kemampuan pemecahan masalah siswa. Penelitian tersebut menunjukan adanya peningkatan kemampuan pemecahan masalah siswa yang semula $65 \%$ menjadi $79 \%$. Dari penelitian Lin, et.al. (2019) yang meneliti dampak board game terhadap motivasi, minat, dan prestasi belajar siswa dalam ilmu kelautan diperoleh hasil bahwa penggunaan board game lebih baik dibandingkan metode pengajaran ekspositori tradisional. Selain itu, Ainurrohmah (2019) telah mengembangkan penggunaan media Board Game untuk pembelajaran bahasa inggris materi pokok greeting and introduction kelas VII SMP. Hasil dari penelitian tersebut ialah media Board Game dapat meningkatkan efektifitas belajar peserta didik.

Berdasarkan penelitian sebelumnya telah memperlihatkan bahwa penggunaan board game dalam pembelajaran terbilang efektif. Oleh karena itu peneliti ingin mengembangkan Board Game untuk membantu meningkatkan minat belajar siswa pada muatan pelajaran PPKn. Sehingga rumusan masalah dalam penelitian ini yaitu bagaimana media pembelajaran yang dapat membantu proses pembelajaran PPKn serta bisa meningkatkan minat siswa pada muatan pelajaran tersebut. Media 
Board Game akan diterapkan pada muatan pelajaran PPKn tema 4 (berbagai pekerjaan). Materi dalam muatan tersebut adalah makna hubungan simbol dengan sila-sila pancasila. Penelitian pada materi tersebut sudah dilakukan oleh Setiawan dan Abdulkarim. Dari penelitian Penerapan Board Game Pancasila Dadu (Pandu) di kelas V MI Al Huda Kota Malang tersebut diperoleh hasil bahwa 91,1\% siswa merespon positif penggunaan media pandu. Sehingga peneliti ingin mengembangkan media serupa, namun berbeda dalam komponen penyusunnya. Dalam Board Game tersebut kubus menjadi komponen yang dilukis dengan gambar simbol dan kata kunci yang mencerminkan nilai-nilai dalam pancasila. Sedangkan, kartu adalah komponen yang akan dikembangkan dalam Board Game ini. Untuk melatih berpikir kritis siswa, kartu yang berkaitan dengan simbol dan nilai-nilai pancasila akan terpisah, sehingga mereka dapat membangun pengetahuannya sendiri.

\section{Metode}

Penelitian ini merupakan penelitian pengembangan atau Reseach and Development yang menghasilkan produk berupa media pembelajaran board game. Research \& Development adalah metode penelitian yang menghasikan sebuah produk dalam bidang keahlian tertentu serta memiliki efektifitas dari sebuah produk tersebut (Saputro, 2017). Model ADDIE adalah model pengembangan yang digunakan pada penelitian ini. Dalam model ini terdapat lima tahapan, yaitu Analisis (Analysis), Perancangan (Design), Pengembangan (Development), Implementasi (Implementation), dan Evaluasi (Evaluation). Tahapan dalam penelitian ini hanya dilakukan hingga tahap development atau pengembangan, sedangkan tahap implementasi dan evaluasi tidak dilakukan. Hal ini dikarenakan board game yang dibuat belum sampai di implementasikan dalam pembelajaran, mengingat kondisi pandemi covid 19 yang mengharuskan pembelajaran jarak jauh (PJJ) diberlakukan. Sehingga, hasil evaluasi dari penggunaannya belum diketahui. Untuk mengetahui kelayakan media Board Game ini maka dilakukan uji validasi para ahli.

Partisipan dalam penelitian ini yaitu siswa dan guru kelas IV dari SD IT El Ma'mur Bogor. Instrumen yang digunakan adalah kuesioner dan instrumen uji validasi. Kuesioner disebar menggunakan google form dalam bentuk link. Kuesioner ini digunakan untuk mengumpulkan data terkait permasalahan pembelajaran PPKn, kesulitan dalam proses pembelajaran tesebut, serta perlunya pengembangan media pembelajaran berbasis permainan. Teknik pengumpulan data yang diperoleh dalam penelitian ini menggunakan data kuantitatif dan kualitatif. Data kualitatif diperoleh dari hasil pengisian kuesioner yang berupa tanggapan maupun saran dari siswa dan guru, sedangkan data kuantitatif diperoleh dari skor tanggapan ahli. Data yang telah dikumpulkan selanjutnya dianalisis menggunakan analisis data desriptif.

Untuk mengetahui hasil validasi dari masing-masing ahli maka dianalisis dengan rumus persentase sebagai berikut.

Skor Validitas Ahli $=\frac{\text { Total skor empirik yang dihasilkan }}{\text { Skor yang diharapkan }} \times 100 \%$

(Mardiki Supriadi, 2015)

Tabel 1. Kriteria Kevalidan Media yang dikembangkan

\begin{tabular}{cc}
\hline Kriteria & Tingkat Validitas \\
\hline $80,01 \%-100 \%$ & Sangat valid \\
\hline $60,01 \%-80,00 \%$ & Valid \\
\hline $40,01 \%-60,00 \%$ & Kurang valid \\
\hline $20,01 \%-40,00 \%$ & Tidak valid \\
\hline $00,00 \%-20,00 \%$ & Sangat tidak valid \\
\hline
\end{tabular}




\section{Hasil}

Sebagaimana tahapan yang terdapat dalam model ADDIE, maka tahap pertama yang dilakukan dalam pengembangan Board Game ini ialah analisis. Untuk mengetahui kebutuhan guru dan siswa terhadap penggunaan media dalam proses pembelajaran PPKn dilakukan analisis awal yaitu dengan studi literatur dari penelitian terdahulu. Selain itu dilakukan juga analisis dengan menyebarkan kuesioner menggunakan google form dalam bentuk link untuk mengetahui terkait permasalahan pembelajaran PPKn, kesulitan dalam proses pembelajaran tesebut, serta perlunya pengembangan media pembelajaran berbasis permainan. Peneliti menyebarkan kuesioner kebutuhan media kepada guru dan siswa kelas IV di SD IT El Ma'mur Bogor. Pada tahap ini juga dilakukan analisis Kompetensi Dasar (KD) yaitu pada KD 3.1 dan 4.1. Analisis dilakukan untuk menentukan indikator pencapaian pembelajaran dari media yang akan dikembangkan. Setelah analisis kompetensi dasar (KD), maka akan didapat identifikasi utama konsep yang harus dituangkan dalam Board Game nantinya.

Dari hasil analisis kebutuhan 27 siswa dari SD IT El Ma'mur, siswa merasa kesulitan mempelajari PPKn karena materinya cukup banyak dan untuk mempelajarinya perlu menghafal. Selain itu dalam pembelajaran PPKn guru lebih sering menggunakan metode ceramah. Sehingga 96,3\% siswa merasa akan tertarik dengan pelajaran PPKn jika dipelajari dengan media berbasis permainan seperti Board Game sehingga guru perlu menyediakannya. 88,9\% siswa juga lebih tertarik untuk membaca materi PPKn jika disajikan secara ringkas, menarik, serta dilengkapi dengan gambar. Siswa juga mengungkapkan bahwa mereka belum memahami betul makna yang terdapat dalam setiap sila-sila pancasila. Padahal, siswa perlu memiliki pemahaman yang baik dalam hal itu.

Berdasarkan hasil pengisian kuesioner, guru mengalami kesulitan untuk menarik minat belajar siswa dalam pembelajaran PPKn dikarenakan ketersediaan media untuk mempelajari PPKn masih kurang memadai dan pembahasannya lebih banyak pada sikap. Guru sangat menyetujui jika media pembelajaran berbasis permainan diperlukan untuk mempelajari PPKn. Selain dapat memancing antusias siswa dalam mengikuti pembelajaran, media berbasis permainan juga diperlukan untuk menarik minat siswa mempelajari PPKn yang cendrung banyak hafalan. Agar mudah dalam penggunaannya, maka media pembelajaran berbasis permainan yang dikembangkan menerapkan cara bermain yang tidak terlalu rumit atau sederhana.

Setelah dilakukan analisis, maka tahap selanjutnya adalah desain. Dalam tahap ini dilakukan desain atau perancangan Board game yang menyesuaikan hasil dari analisis yang telah didapatkan. Selain itu, peneliti juga mengumpulkan berbagai referensi yang diperlukan untuk menunjang isi dalam media tersebut. Tahap desain dilakukan dengan menentukan komponen-komponen apa saja yang diperlukan dalam Board Game. Selanjutnya dibuat storyboard untuk memudahkan tahap pengembangan. Board Game didesain menggunakan aplikasi canva.

Tahap ketiga sekaligus menjadi tahap terakhir dalam model ADDIE disini adalah pengembangan. Pada tahap ini, pengembangan media Board Game mulai dilakukan dengan berpatokan pada storyboard yang telah dibuat sebelumnya. Tampilan Board Game dibuat semenarik mungkin dengan gambar-gambar yang menyesuaikan isi atau konten materi yang disajikan, serta ketepatan pemilihan warna.

Untuk menganalisis kesesuaian produk dengan materi, dan mengukur kelayakan produk yang dihasilkan, maka terlebih dahulu dilakukan validasi oleh para ahli. Uji validasi ini dilakukan agar media yang dikembangkan dapat diketahui kebenaran 
dan ketepatannya sebelum nantinya diterapkan sebagai solusi media dalam pembelajaran PPKn. Media Board Game divalidasi oleh ahli media dan ahli bahasa. Ahli media dan bahasa merupakan dosen dijurusan Pendidikan Guru Sekolah Dasar di Universitas Majalengka.

Tabel 1. Hasil Validasi Ahli Media

\begin{tabular}{|c|c|c|}
\hline No & Butir Penilaian & Skor \\
\hline 1 & $\begin{array}{l}\text { Ketepatan pemilihan gambar yang digunakan pada tampilan } \\
\text { board game }\end{array}$ & 4 \\
\hline 2 & Ketepatan proporsi warna tampilan board game & 4 \\
\hline 3 & Konsistensi proporsi tampilan (tata letak teks dan gambar) & 4 \\
\hline 4 & Tidak terlalu banyak kombinasi jenis warna & 4 \\
\hline 5 & Kemenarikan tampilan papan permainan & 4 \\
\hline 6 & Kemenarikan tampilan kartu & 4 \\
\hline 7 & $\begin{array}{l}\text { Kejelasan nama board game (PAMACABOGA) dalam } \\
\text { memberikan gambaran umum permainan }\end{array}$ & 4 \\
\hline 8 & Ketepatan pemilihan jenis font pada tampilan board game & 4 \\
\hline 9 & Ketepatan ukuran huruf agar mudah dibaca & 4 \\
\hline 10 & Ketepatan warna teks agar mudah dibaca & 3 \\
\hline 11 & $\begin{array}{l}\text { Kesesuaian ukuran gambar pada papan permainan (cover } \\
\text { depan, cover belakang, dan dalam/isi) }\end{array}$ & 4 \\
\hline 12 & Kesesuaian ukuran kartu dalam board game & 4 \\
\hline 13 & $\begin{array}{l}\text { Gambar pada kartu ilustrasi perilaku merangsang siswa untuk } \\
\text { belajar menganalisis }\end{array}$ & 3 \\
\hline 14 & Penampilan pusat pandang (center point) baik & 3 \\
\hline 15 & $\begin{array}{l}\text { Kesesuaian penggunaan board game dengan materi } \\
\text { pembelajaran }\end{array}$ & 3 \\
\hline 16 & $\begin{array}{l}\text { Kelengkapan informasi pada lembar pendukung pengunaan } \\
\text { media }\end{array}$ & 4 \\
\hline 17 & Tampilan lembar pendukung penggunaan media & 4 \\
\hline 18 & Kemudahan dalam penggunaan Board game & 4 \\
\hline 19 & $\begin{array}{l}\text { Media merangsang siswa untuk membangun pengetahuannya } \\
\text { sendiri dan juga keaktifan untuk mencari sumber bacaan }\end{array}$ & 3 \\
\hline 20 & Media dapat menarik minat belajar siswa SD sebagai pengguna & 3 \\
\hline \multicolumn{2}{|c|}{ Skor yang dihasilkan } & 74 \\
\hline \multicolumn{2}{|c|}{ Skor yang diharapkan } & 100 \\
\hline
\end{tabular}

Berdasarkan hasil validasi yang dilakukan oleh ahli media diperoleh skor presentase yakni sebesar $74 \%$. Merujuk pada kriteria kevalidan media, maka media Board Game yang dikembangkan dinyatakan valid. Menurut Akbar (dalam Mardiki Supriadi, 2015) hasil persentase dari validasi ahli media pembelajaran dapat diambil kesimpulan bahwa media yang dikembangkan dapat digunakan karena hasil persentase memperoleh skor melebihi skor minimal yakni 60,01\%. Ahli media menyimpulkan, Board Game layak untuk digunakan sebagai media pembelajaran.

Tabel 2. Hasil Validasi Ahli Bahasa

\begin{tabular}{clc} 
No & \multicolumn{1}{c}{ Butir Penilaian } & Skor \\
\hline 1 & $\begin{array}{l}\text { Kalimat yang digunakan dalam Board game merupakan } \\
\text { kalimat efektif }\end{array}$ & 4 \\
\hline 2 & $\begin{array}{l}\text { Kalimat yang digunakan dalam kartu merupakan kalimat } \\
\text { efektif }\end{array}$ & 4 \\
\hline 3 & $\begin{array}{l}\text { Pertanyaan yang disajikan dalam kartu sesuai dengan } \\
\text { tingkat perkembangan intelektual siswa }\end{array}$ & 4 \\
\hline 4 & Kalimat yang digunakan tidak menimbulkan makna ganda & 4 \\
\hline 5 & Bahasa yang digunakan mudah dipahami & 4 \\
\hline 6 & Penggunaan kata sesuai PUEBI & 24 \\
\hline Skor yang dihasilkan & 30 \\
\hline
\end{tabular}


Hasil validasi yang dilakukan oleh ahli bahasa terhadap media yang dikembangkan, memperoleh skor persentase yakni sebesar 80\%. Oleh karena itu, berdasarkan kriteria yang telah ditetapkan maka media ini tergolong valid. Saran yang diberikan oleh ahli bahasa yaitu EYD perlu diperhatikan lagi. Ahli bahasa menyimpulkan Board Game layak untuk digunakan dengan revisi sesuai saran.

\section{Pembahasan}

Media pembelajaran yang dinamakan PAMACABOGA merupakan singkatan dari Pancasila Matching Card Board Game. Dari nama tersebut dapat dipahami bahwa komponen permainan berupa kartu. Menurut Limantara (2015), Board game merupakan suatu permainan non elektronik yang memakai papan sebagai komponen utamanya, serta komponen lainnya seperti kartu token, uang kertas, dan lain sebagainya. PAMACABOGA dapat digunakan untuk membantu guru dalam menyampaikan materi PPKn yaitu makna hubungan simbol dengan sila-sila pancasila. Media pembelajaran ini akan membantu siswa dalam mempelajari dan memahami satu persatu makna hubungan simbol dengan sila-sila pancasila.

Board Game PAMACABOGA mengadopsi board game seperti jenis puzzle, hanya saja komponen yang digunakan adalah kartu. Sehingga yang dibutuhkan dalam penggunaan Board Game ini ialah ketepatan siswa dalam menempatkan atau mencocokan kartu sesuai papan yang disediakan. Namun, untuk bisa menempatkan kartu-kartu tersebut agar mendapatkan poin, siswa perlu menjawab terlebih dahulu pertanyaan yang terdapat pada bagian belakang kartu simbol, kartu makna simbol, serta kartu makna sila. Salah satu fungsi board game adalah mengharuskan pemainnya untuk berpikir, memecahkan masalah, dan mengambil keputusan (Safitri, 2019).

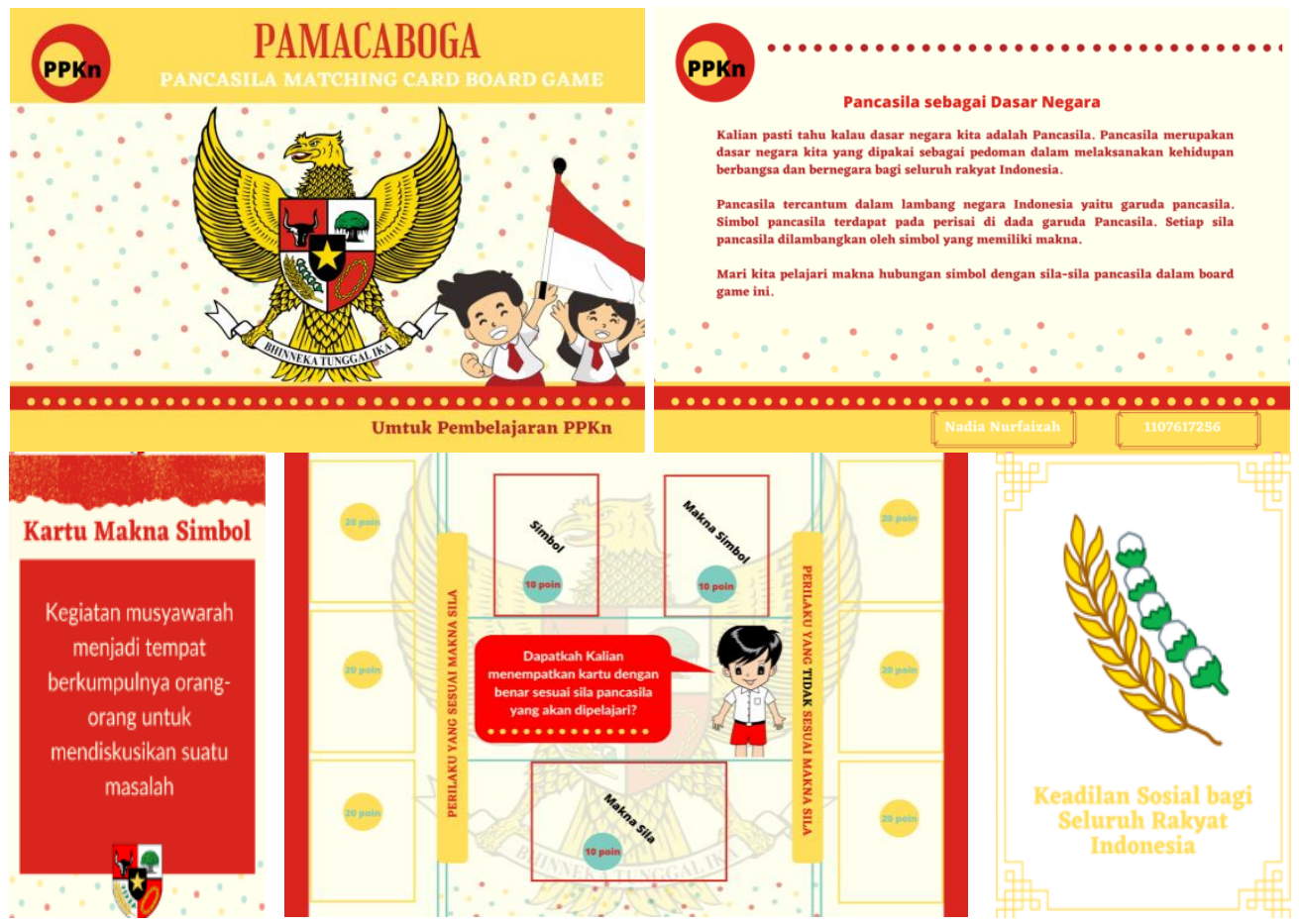

Gambar 1. Gambar Media Board Game PAMACABOGA

Media pembelajaran yang menarik akan berdampak positif dalam proses pembelajaran. Berdasarkan skor yang diberikan ahli media terhadap kemenarikan media adalah 4, yang mengartikan bahwa Board Game PAMACABOGA menarik. 
Benzies menjelaskan bahwa untuk melibatkan siswa belajar dalam konteks yang menyenangkan diperlukan pemilihan strategi dan media pembelajaran yang menarik (Ratminingsih, 2018). Hasil penelitian yang dilakukan oleh Pratiwi, et.al. (2020) memberikan penguatan bahwa penggunaan media dalam kegiatan pembelajaran dapat membantu daya ingat siswa, serta menimbulkan perasaan senang saat mengikuti pembelajaran jika ditampilkan dengan desain gambar dan warna yang menarik.

Tampilan Board Game PAMACABOGA dibuat dengan menarik serta dilengkapi gambar-gambar yang disesuaikan dengan materi yang disajikan yaitu pancasila. Ketepatan pemilihan gambar dalam Board Game ini sudah dinyatakan baik oleh ahli media. Maghfirothi (2013) menyatakan bahwa ilustrasi berupa gambar berfungsi untuk menarik perhatian maupun minat belajar, memperjelas ide, atau mengilustrasikan fakta. Dari segi pemilihan warna, Board Game sudah memiliki ketepatan proporsi warna yang baik serta kombinasi warna yang tidak terlalu banyak. Menurut Wahyuningsih dan Setiadi (2019), Warna memiliki peranan penting dalam sebuah media Board Game. Penggunaan warna yang mencolok baik untuk memfokuskan perhatian, namun apabila berlebihan maka dapat mengganggu penglihatan.

Media Board Game erat kaitannya dengan penyajian gambar, hal ini dikarenakan gambar merupakan salah satu informasi yang dapat disajikan dalam media Board Game (Putri, 2020). Board Game PAMACABOGA tergolong kedalam jenis media berbasis permainan yang memperhatikan aspek visual. Media dengan tampilan visual seperti gambar akan lebih mudah ditangkap oleh siswa terlebih bagi yang bergaya belajar visual. Oleh Levie \& Levie menyimpulkan dari hasil-hasil penelitian bahwa belajar melalui stimulus gambar dan stimulus kata atau visual dan verbal akan memberikan hasil belajar yang lebih baik untuk mengingat, mengenali, mengingat kembali, serta menghubungkan fakta dan konsep (Sukiman, 2012). Pendapat tersebut juga didukung oleh Dale (1969) yang memperkirakan bahwa $75 \%$ hasil belajar diperoleh melalui indera pandang, $13 \%$ melalui indera dengar, dan sekitar $12 \%$ melalui indera lainnya.

Media Board Game dirancang agar memberikan aktivitas pembelajaran yang dilakukan dalam kelompok. Salah satu upaya yang dapat dilakukan guru agar dapat membangkitkan minat dan motivasi siswa dalam pembelajaran adalah dengan menerapkan model kerja kelompok (Ginting, 2012). Dengan adanya media pembelajaran yang berkaitan dengan aktivitas belajar sambil bermain, siswa akan tertarik dan menumbuhkan minat untuk mengikuti pembelajaran (Safitri, 2019). Salah satu faktor yang mempengaruhi minat belajar menurut Slameto (2011) dapat diatasi dengan penyajian materi yang lebih praktis dan berseni. Media yang dikembangkan memberikan kepraktisan kepada siswa dengan penyajian materi makna hubungan simbol dengan sila-sila pancasila dalam sebuah permainan papan dengan komponen berupa kartu. Selain itu Board game didesain dengan tampilan yang menarik atau dapat dikatakan berseni.

Board game yang dimainkan secara bersama dalam sebuah kelompok akan menambah semangat serta antusias belajar siswa. Menurut Desmita (2009), siswa sekolah dasar cenderung lebih senang bermain, bekerja dalam kelompok, dan melakukan sesuatu secara langsung. Selain itu Board Game dapat membantu siswa lebih mudah mengingat tanpa perlu menghafal karena siswa sendiri yang terlibat langsung dalam permainannya. Hasil ini mendukung penelitian yang dilakukan oleh Khoiruman (2020) yang mengungkapkan bahwa anak-anak akan lebih mudah mengingat apa yang dimainkannya, atau dengan kata lain mereka lebih mudah menghafal dengan sebuah permainan. Para ahli pendidikan anak pada risetnya juga 
menyatakan cara belajar yang paling efektif untuk anak ialah melalui permainan, yaitu bermain sambil belajar.

Prinsip VISUALS, yaitu Visible (Mudah dilihat), Interesting (Menarik), Simple (Sederhana), Useful (Isinya berguna/bermanfaat), Accurate (Benar atau dapat dipertanggungjawabkan), Legitimate (Masuk akal/sah), dan Structured (Terstruktur/tersusun dengan baik) menurut Mukminan (2008) perlu diperhatikan dalam pengembangan sebuah media pembelajaran. Menurut Nieven (dalam Ariani et al., 2017) suatu media dapat dikatakan baik jika memenuhi aspek-aspek kualitas antara lain validitas, kepraktisan, dan keefektifan. Media Board Game PAMACABOGA memiliki kategori layak menurut 3 pakar kerena memiliki perolehan skor pada masing-masing indikator adalah 3 dan 4 . Skor yang diberikan oleh ahli media terhadap kemudahan cara bermain media yang dikembangkan adalah 4 atau dengan kategori baik. Sehingga dapat diartikan bahwa Board Game PAMACABOGA sudah memenuhi prinsip simple. Dari segi kemenarikan media ini pun tergolong baik dengan perolehan skor 4 .

Berdasarkan penelitian serupa yang dilakukan oleh Risnani (dalam Putri, 2020) yang mengembangkan Media Pembelajaran Permainan Papan Biologi (Bio Board Game) Materi Sistem Ekskresi menunjukkan bahwa penggunaaan Board Game mampu meningkatkan minat belajar dan hasil belajar siswa. Hasil-hasil penelitian yang diperoleh pun telah mendukung media pembelajaran yang dikembangkan. Dengan demikian dapat disimpulkan bahwa Board Game PAMACABOGA dapat digunakan sebagai media pembelajaran PPKn yang membantu meningkatkan minat belajar siswa.

\section{Simpulan}

Berdasarkan uraian hasil penelitian di atas, dapat disimpulkan bahwa media pembelajaran ini dapat meningkatkan minat belajar siswa karena memiliki tampilan yang menarik, disajikan dengan ringkas dan dilengkapi dengan gambar, serta dimainkan secara berkelompok, sehingga menambah antusias atau perasaan senang siswa untuk mengikuti pembelajaran PPKn. Selain dapat meningkatkan minat belajar, Board Game juga dapat memudahkan siswa untuk menghafal materi PPKn yang banyak karena siswa terlibat langsung dalam permainannya. Berdasarkan perolehan hasil uji validasi kelayakan Board Game materi makna hubungan simbol dengan sila-sila pancasila yang terdapat pada tema 4 kelas IV SD, menunjukkan bahwa media pembelajaran tersebut layak digunakan dengan perolehan presentase $74 \%$ dari ahli media dan $80 \%$ dari ahli bahasa. Sehingga, Board game PAMACABOGA dapat dijadikan sebagai sebuah solusi media pembelajaran pada muatan pelajaran PPKn.

\section{Saran}

Penelitian pengembangan ini menghasilkan suatu media Board Game materi makna hubungan simbol dengan sila-sila pancasila, muatan pelajaran di Kelas IV Tema 4 (Berbagai Pekerjaan) yang diberi nama PAMACABOGA. Oleh karena itu saran berkaitan dengan media board game yang dihasilkan adalah:

1. Dalam pemanfaatan media Board Game ini, guru perlu menjadi pembimbing, untuk itu guru perlu memperhatikan lembar panduan permainan yang disediakan

2. Media ini dapat digunakan untuk pembelajaran yang berkaitan dengan pancasila. Karena media ini menyajikan lima sila secara utuh 
3. Board Game dapat dijadikan bahan penelitian lanjutan dalam pembelajaran PPKn dengan materi lainnya

4. Penelitian yang telah dilakukan belum sampai tahap implementasi serta evaluasi, dan hanya sebatas pada perancangan pengembangan media dan validasi. Peneliti selanjutnya diharapkan dapat melanjutkan sampai implementasi maupun evaluasi

\section{Referensi}

Ainurrohmah, D. A. (2019). Pengembangan Media Board Game Pada Mata Pelajaran Bahasa Inggris Materi Pokok Greeting and Introduction Kelas VII Di Smp Dewantara Surabaya. 1-10.

Andrew, J., Henry, S., Yudhisthira, A. N., Arifin, Y., \& Permai, S. D. (2019). Analyzing the factors that influence learning experience through game based learning using visual novel game for learning pancasila. Procedia Computer Science, 157, 353-359.

Ariani, P., Daningsih, E., \& Yokhebed. (2017). Kelayakan Media Flipbook Upaya Pencegahan Pencemaran Udara Kelas X. Jurnal Pendidikan Dan Pembelajaran Khatulistiwa, 1-11.

Christopher, A. E., Waluyanto, H. D., Wahyudi, A. T., Visual, D. K., Seni, F., \& Petra, U. K. (2019). Perancangan Board Game Pembelajaran Toleransi Terhadap Perbedaan Pada Pelajaran Ppkn. Jurnal DKV Adiwarna, 1-9.

Ginting, N. (2012). Meningkatkan Minat Belajar Siswa dengan Menggunakan Model Pembelajaran Kooperatif Tipe Number Head Together (NHT) pada Mata Pelajaran IPA Materi Pokok Gaya Magnet di Kelas V SD. Jurnal Handayani, $44-50$.

Hamka L, Ms. H., Sitti Saenab, M., \& Sitti Rahma Yunus, Mp. (2017). Sumber Belajar Penunjang Plpg 2017. Jurnal Online, Kementerian Pendidikan dan Kebudayaan Direktorat Jenderal Guru dan Kependidikan, 12-13.

Limantara, D., Heru, Waluyanto, D., \& Zacky, A. (2015). Perancangan Board game Untuk Menumbuhkan Nilai-Nilai Moral Pada Remaja. Jurnal Desain Komunikasi Visual Adiwarna, 1(6), 78547.

Lin, Y. L., Huang, S. W., \& Chang, C. C. (2019). The impacts of a marine science Board Game On Motivation, Interest, and achievement in Marine Science Learning. Journal of Baltic Science Education, 18(6), 907-923.

Mardiki Supriadi, L. V. H. (2015). Pengembangan Media Virtual Reality Pada Muatan Pelajaran IPA Kelas VI Sekolah Dasar. Jurnal Teknologi Pendidikan (JTP), 8(2), 241-255.

Permanda, T. P.:Wahyudi. (2020). Efektivitas Media Board Game Untuk Meningkatkan Kemampuan Pemecahan Masalah Siswa Sekolah Dasar The Effectiveness of Board Game to Enhance The Elementary School Students Problem Solving Skill Pendahuluan JSD : Jurnal Sekolah Dasar | 19. 1(1), 1824.

Putri, D. R. (2020). Pengembangan Media Pembelajaran Green Science Board Game ( GREECEBOME ) pada Materi Pencemaran Lingkungan terhadap Minat Belajar Siswa. In Skripsi. Universitas Negeri Semarang.

Rahmayani. (2016). Implementasi Manajemen Pembelajaran Ppkn Kurikulum 2013. Jurnal Manajer Pendidikan, 10(2), 143-148.

Ratminingsih, N. M. (2018). Implementasi Board Games Dan Pengaruhnya Terhadap Hasil Belajar Bahasa Inggris. Jurnal Ilmu Pendidikan, 24(1), 19.

Riyan Cahya, S., \& Harmanto. (2018). Kemampuan Berpikir Kritis Siswa Pada Mata Pelajaran PPKn Di SMP Negeri 1 Balong, Kecamatan Balong, Kabupaten Ponorogo. E Journal Kajian Moral dan Kewarganegaraan, 6(2), 291-305.

Rusmiati. (2017). Pengaruh Minat Belajar Terhadap Prestasi Belajar Bidang Studi Ekonomi Siswa Ma Al Fattah Sumbermulyo. Jurnal Ilmiah Pendidikan Dan 
Ekonomi, 1(1), 21-36.

Safitri, W. C. D. (2019). Efektivitas Media Board Game terhadap Kemampuan Pemecahan Masalah pada Pembelajaran Tematik di SD. Mimbar PSGD Undiksha, 7(2), 72-78.

Saputro, B. (2017). Manajemen Penelitian Pengembangan (Research \& Development) bagi Penyusun Tesis dan Disertasi. In Journal of Chemical Information and Modeling, 53(9).

Saswandi, T., Muhammadiyah, S., Jambi, W., \& Penuh, D. S. (2014). Teaching Style And Students' Interest In Learning English. Jurnal Penelitian Universitas Jambi Seri Humaniora, 17(1), 33-39.

Setiawan, N. H. A., \& Abdulkarim, A. (2020). Application of Board Game Pancasila Dadu (Pandu) in Civic Learning. Proceedings of the 2nd Annual Civic Education Conference (ACEC 2019), 467-470.

Sukiman. (2012). Pengembangan Media Pembelajaran. Yogyakarta: Pedagogia.

Sulasteri, S., Rusydi Rasyid, M., \& Akhyar, M. (2018). the Effect of the Use of Learning Media Based on Presentation Media on Interest and Mathematical Learning Outcomes. MaPan, 6(2), 221-236.

Syawaluddin, A., Afriani Rachman, S., \& Khaerunnisa. (2020). Developing Snake Ladder Game Learning Media to Increase Students' Interest and Learning Outcomes on Social Studies in Elementary School. Simulation and Gaming, 51(4), 432-442. 